\title{
POPULAR MEDIA AND ITS ABILITY TO (RE)FORM PERCEPTIONS ABOUT AFRICA AND BLACKNESS:
}

\section{BLACK PANTHER}

\section{A REFLECTION ON GODFRIED A. ASANTE \& GLORIA NZIBA PIND: (RE)IMAGINING AFRICAN FUTURES: WAKANDA AND THE POLITICS OF TRANSNATIONAL BLACKNESS}

\section{ESZTER COLUBICS}

\section{M.A. STUDENT, INTERNATIONAL RELATIONS}

DEPARTMENT OF POLITICAL SCIENCE AND INTERNATIONAL STUDIES, UNIVERSITY OF PÉCS ESZTER.COLUBICS@GMAIL.COM

This reflection essay, with the help of studying Black Panther, describes how popular media form or potentially reform our perceptions about Africa and Blackness. The introduction creates a base for understanding the movie's place in public opinion and how critics have reviewed it; and raises the issues that are to be addressed. Reflecting upon Asante \& Pind's paper, the analysis starts with Africa's (Wakanda) portrayal and how it reinforces certain stigmas and stereotypical thinking, but at the same time how the afrofuturistic setting offers to change our presumptions and helps to create a possibly better future for Black people by imagining an Africa, unaffected by Western colonialism. The characters are also flashed out, putting more emphasis on the main heroes: T'Challa and Killmonger. I examine their personalities, actions and where they come from, elaborating on the problematic aspects of the message these convey by feeding us the same reoccurring Hollywood storylines behind black character masks. Ultimately, I ask the question: Does Black Panther deserve to be called a milestone for Black people in cinema or is it just another form of white exploitation?

Black Panther, Afrofuturism, Blackness, Africa, neocolonialism, popular media 
The Marvel Cinematic Universe released its long-awaited blockbuster film, Black Panther, in 2018 to global enthusiasm. It was a big success all over the world not only amongst general audiences, but critics and scholars alike praised the movie, calling it a "celebratory cinematic response to decades of racial injustice in Hollywood" while also pointing out popular culture's limited means to transform structural oppressions. (Griffin-Rossing, 2020) The hype surrounding Black Panther hardly faded and the anticipated 2022 sequel will only reinforce it. Describing the importance of the film, Adam Serwer wrote:

"Black Panther is a love letter to people of African descent all over the world. Its actors, its costume design, its music, and countless other facets of the film are drawn from all over the continent and its diaspora, in a science-fiction celebration of the imaginary country of Wakanda, a high-tech utopia that is a fictive manifestation of African potential unfettered by slavery and colonialism."(Serwer, 2020)

Despite the overall positive welcome, some scholars remind us that cinema, no matter how influential it may be, is limited in respect to bringing about big structural changes. Christopher Lebron goes against Serwer's idea of a perfect afrofuturistic film and contends that:

"Black Panther is not the movie we deserve [...] Why should I accept the idea of a black American disposability from a man in a suit, whose name is synonymous with a radical uplift but whose actions question the very notion that black lives matter?"(Lebron, 2018)

The unmistakable theme of the movie, that revolves around race, slavery and colonialism, has fueled disagreements about its purpose and effectiveness in trying to challenge stigmas and leave those behind by creating a futuristic idea of what Africa and Africans can be. Representations in the media have material consequences; it has "the power to shape, influence and suggest who people are and subsequently how they can acceptably be treated." (Griffin, 2012: 148.) Precisely because of this, it is principal to look at Black Panther, as a cultural phenomenon based on its farreaching influence, and analyze what it means, what kind of message it conveys and what impact it has on how people see Africans and Africa and engage with concepts like Blackness.

\section{The (Western) Portrayal of Africa}

The way we perceive Africa starts with its name. There is little agreement on the sources and original meaning of the word "Africa", but we know the usage of the term started in Roman times and initially referred to North Africa, before it was extended to the whole continent. However, throughout the years it became increasingly confined to "sub-Saharan Africa", which nowadays is seen as the primary location of the "real" Africa. North Africa and its countries, like Algeria, Libya or 
Egypt, are somehow left out from the "real" Africa concept and characterized exclusively as Arab, which erases the history and culture of these lands that existed before the Islam takeover. The picture of Africa is so closely tied to and fixated on the south of the Sahara regions that it "ultimately offers us a racialized view of Africa, Africa as biology, as the 'black' continent." (Zeleza, 2006: 15) It is common both within and outside the continent and this is why Black Panther concerns itself with "Black Africa".

Amongst the issues the film tries to tackle is slavery and colonialism, more specifically white colonialism. Black Panther envisions a world (Wakanda) with Black life left untouched, undisturbed and independent. (Hudson, 2018) The screenwriters seem to suggest that everything bad happening with Africans, more notably slavery, has to do with the West exclusively. As if they forgot that slavery in Africa predates colonialism and as early as the $8^{\text {th }}$ century a full third of the continent was enslaved by African Islamic states. Even now an estimated 660,000 people are deprived of their freedom. It is not to say that the West is without fault but what good does it do to belittle one of the few forces ever to encourage the abolition of slavery in the African continent? (Knowles, 2018)

Criticism of this kind is closely tied to black America and it has little to offer to the people of Africa. Although the film makes an effort to portray African cultures, it fails to show the diversity of it. For instance, it simplifies and moulds languages into one, which does not help to improve our understanding of the continent and the variety of its cultures. However, we should keep in mind that this is merely a two and a half hour movie, and there is only so much you can put into it. It is a difficult task to show the historical background leading to the contemporary situation, while creating futuristic visions and opportunities for generations to come. Not even mentioning the challenges of displaying how the representation of Blackness means different for Africans in the diaspora and people in continental Africa.

Sofia Samatar states that afrofuturism is rarely traced back to the African continent and it focuses mainly on global Blackness and its orientation towards outer space. (Samatar, 2018) Africans cannot fully engage with the movie and it is not meant for them, which is why there was no hurry to premiere it on the continent (few could have afforded the $\$ 10$ ticket to the theatre anyway). (Gathara, 2018) If your purpose is to embrace Black people and Africans all over the world, can you allow yourself such distancing from Africa while paradoxi-

The unmistakable theme of the movie, that revolves around race, slavery and colonialism, has fueled disagreements about its purpose and effectiveness in trying to challenge stigmas and leave those behind by creating a futuristic idea of what Africa and Africans can be. 
cally putting so much emphasis on it? Is it really about the celebration of the origin country and its culture or just another form of white exploitation? It is no secret that Black Panther is part of the highly successful Marvel franchise and from that derives its limitations on outlining intricate political situations. It is a Disney production and the company's undoubtable history of making use of depicting people of colour (Pocahontas, Mulan, Aladdin, The Princess and the Frog) makes one wonder about the real intentions of creating such a movie. Could it be just a form of capitalist exploitation in the name of social justice? (Asante-Pind, 2020) Khan says Black Panther serves as an example of this phenomena, when African heritage becomes only a decorative element, granting a nice sheen to western movies, without giving thorough attention to the culture and traditions. (Khan, 2019)

Also worth to note that there are very few parts of the film that have been actually shot in the African continent, although the director visited Kenya, South Africa and the Kingdom of Lesotho as well, which he based much of Wakanda's concept on. But it leaves the question: why did not they try to benefit the people and shot much of the film in the country they claim to help? Why were CGI enhanced backgrounds used instead of real landscapes? It is evident that creating a superhero movie in the $21^{\text {st }}$ century requires modern filmmaking technologies (CGI, 4K+3D cameras, VR cameras, HMCs, facial movement recognition programmes etc.), but when formulating opinions and transforming stereotypical thinking is the goal, it is crucial to draw from reality. The movie paints a spectacular picture of Wakanda but the fact that it does not have much physical (more inspirational) tie to Africa takes away from its merits.

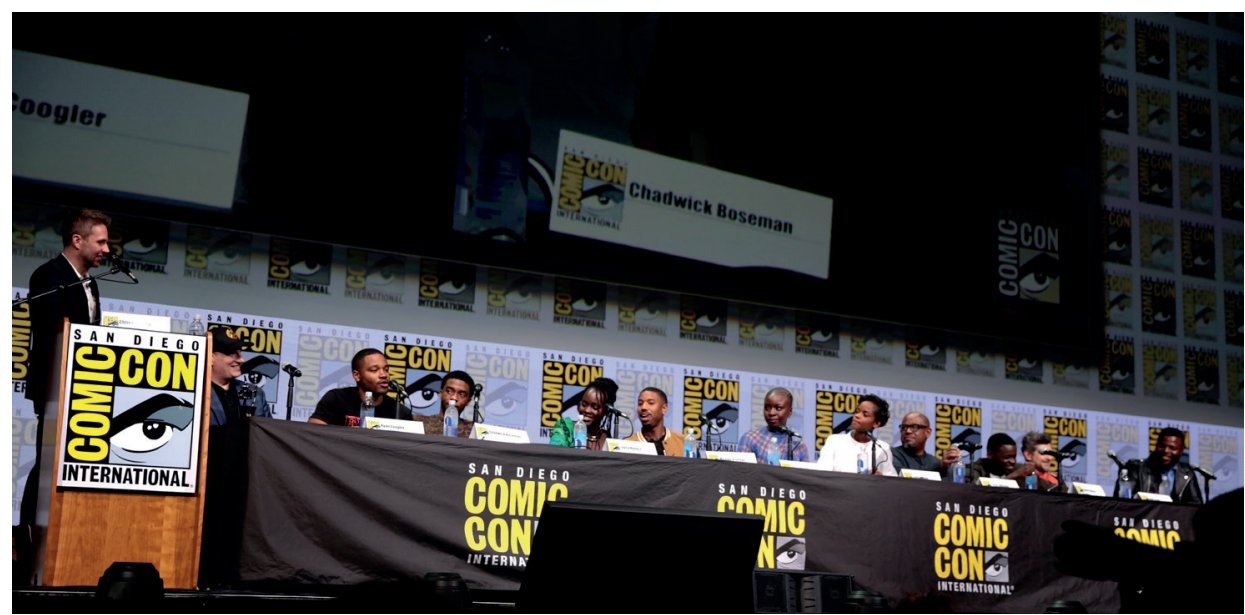

Black Panther cast. Chris Hardwick, Kevin Feige, Ryan Coogler, Chadwick Boseman, Lupita Nyong'o, Michael B. Jordan, Danai Gurira, Letitia Wright, Forest Whitaker, Daniel Kaluuya, Andy Serkis and Winston Duke speaking at the 2017 San Diego Comic Con International, for "Black Panther", at the San Diego Convention Center in San Diego, California.

Source: Gage Skidmore, wikimedia. 


\section{A Confusing Afrofuturist Vision}

"Afrofuturist creations empower African and African diasporic subjects to centre Africana ontologies and epistemologies in ways that fundamentally refigure futurism by weaving together the spiritual and technological, embodied and mechanical, natural and created." (Hanchey, 2020: 260)

Black Panther and its setting are afrofuturistic because "it disrupts our understanding of Blackness by rethinking the past, present, and futures of the African diaspora." (White, 2018: 422) "Afrofuturism unchains the mind" (Womack, 2013: 44) and "powerful descriptions of the future have an increasing ability to draw us towards them, to command us to make them flesh." (Eshun, 2003: 290-91) But, this futuristic theme does not capture the complexity of African histories and identities, and yields too much to Western neocolonial fantasies of Africa.

Let us now take a look at a scene from the movie. In the beginning, T'Challa and his guard Okoye stop kidnappers, finding Nakia (T'Challa's love interest) undercover, trying to save the women as well. The rescued respond with saying thank yous while bowing to the heroes. The heroes fly away leaving the victims behind in the jungle. For one, the jungle setting is not insignificant, since the forest implies associations both to primitivistic portrayals of Africa and Africans. (Hanchey, 2020: 264) Noteworthy that "Muslim" Africa (North Africa) and Muslims are removed from the romanticized Wakanda except the above-mentioned scene that associates them with violence and also positions Muslim women in need of help. "As such, Black Panther participates in Hollywood's devotion to Islamophobic storytelling." (Griffin-Rossing, 2020) Also important to add that by putting Wakanda in a privileged position, even though it helps create an idealistic picture of what Africa could be outside of coloniality, sets them apart and leaves the stereotypes of African nations in place. The African characters (like the women in said scene) other than Wakandans are one-dimensional and used as foils for the Wakandan heroes, repeating the logics of whitewashing and white saviorism behind Black character masks. (Hanchey, 2020: 263) Wakanda itself is challenging stereotypes, since it is a nation with technological power, wealth and military might (elevating them above other African nations) reaching at least the level of the US if not more. But besides Wakanda, the representation of the continent pretty much stays the same and serves only as a glorified setting for the plot.

Another problematic aspect of this futuristic Africa, is the issue of giving aid. Sylvia Wynter says that "international aid often functions as a neocolonial extension of colonial power structures." (Hanchey, 2020: 260) Giving aid is one of the main themes of the movie, starting from the above-mentioned scene, in which Nakia and T'Challa, shortly after they save the kidnapped women, argue about Wakanda's role of helping black people around the world. As we established before, aid functions as a new way of colonialism and those countries who were ravaged by it, now suffer from loans that leave them worse off economically than before and keep them in a 
never-ending cycle of debt to the West. For instance, "when aid flows to Africa were at their peak, poverty in Africa rose from 11\% to a staggering $66 \%$ ". (Moyo, 2009: 49) Aids that flow in are ineffective, they even make things worse and that suggests the need for even more aid. What lies behind the West's generosity? Hanchey explains this as such: "Western ideology equates Africa with ontological emptiness in order to extend white masculine humanity through the West's desire to be exceptional, to be saviours." (Hanchey, 2020: 262) In other words the West uses aid-giving as a device for keeping its colonial influence and to appear righteous while doing it. It results in a paternalistic relationship between the provider and the recipient and may lead to the feeling of supremacy on the part of the aid-giver. (Moyo, 2009) This is why it feels a little controversial when Wakanda adorns its role as a saviour, because it reenacts the Western narrative. Jenna N. Hanchey confirms this by saying that "although Black Panther challenges some neocolonial assumptions of agency and development through centring an African country as the developed aid-giver, it ultimately reinforces colonial modernity, thereby hindering the film's Afrofuturist potential." (Hanchey, 2020: 261-62) It sends a weird futuristic message, when the kingdom in focus pretends to be a third world country while underneath its disguise lies an incredible technologically advanced nation. According to Slaats, it can be understood like this: "See, underneath every seemingly primitive African hide a (possible) modern Westerner!" (Slaats, 2018)

The isolation of Wakanda is also troublesome. It depicts a Eurocentric view, when a society isolates itself while others are suffering. What we see with aid-giving, we see with isolation. This mentality goes against African philosophy, where they say: a person becomes human only amid others. (Asante-Pind, 2020)

Considering all of the above, one of the most important aspects of Africa's representation is that it "is always imagined, represented and performed in relation to master references, - Europe, Whiteness, Christianity, Literacy, Development, Technology - mirrors that reflect Africa in peculiar ways, reducing the continent to particular images, to a state of lack." (Zeleza, 2006: 16) The portrayals are mostly incapable to break away from comparisons and look at Africa through a postcolonial lens. Nevertheless, the portrayal of Wakanda has its silver lining as well. Its level of development is different than that of the West; it depends on tradition, spirituality, and nature in addition to technology. Wakandan culture integrates magic and metal, using the heart-shaped herb given to them by the panther goddess Bast to anoint their leaders - who garb themselves in clothes made from vibranium. The refusal to separate technology and spirituality is in line with Afrofuturist sensibilities that destabilize white, Western technofuturist norms. (Nelson, 2002)

\section{The Depiction of the Characters}

The cast of Black Panther is predominantly black, following executive producer Nate Moore and director Ryan Coogler. As we already underscored, representation does matter, and this movie makes us think about the depiction of Africans more deeply. On the surface there are obvious problems with some portrayals, such as M'Baku 
and his tribe, who dress like monkeys and literally make oo-oo-oo sounds, deepening some of the major stereotypical images about Africans. (Slaats, 2018) Even though he is portrayed like this in the comic books, this was a missed chance on the developers part for not making a useful creative decision and choosing to bring a degrading element to the screen instead. Zeleza also points out that the tribal markings on several characters' bodies reinforce a homogenized "African authenticity" reminiscent of photographs in antiquated National Geographic. (Zeleza, 2018) These representations which try to show some kind of "African authenticity" do not express the contemporary understanding of Africa and African bodies.

Most of the main actors were already involved with successful Hollywood movies, just like how the director already made a name for himself with films such as Creed. Their appearance was not directly beneficial for Africa, since they were already in a position to play a role in a blockbuster or direct one. Although seeing them on the screen gives a chance for black people to relate and feel connected to the characters. Chadwick Boseman, who plays T'Challa comments about African heritage and says that it is "a great opportunity to develop a sense of what that identity is, especially when you're disconnected from it." (Smith, n.d.)

When asked about the characters, Coogler tells his experience as a black man figuring out his identity: "That's something I've always struggled with as a person". For that reason, he tries to focus on the person, he shows "not just identity, but names." (Smith, n.d.) He explores the sense of self in his movies a lot and Black Panther is no exception. It deals with Blackness and raises questions about transnationality as well, which is very apparent amongst the diasporic Africans:

\footnotetext{
"When you are in Europe, people say to us, you are not European, you are African.
}

And when we are in Africa, African people say to us, you are not African, you are European." 
The above quote is from an interview with a young woman who was born in Africa and moved to France later on. A clear parallel can be made with her and Killmonger's character, who was also born in Wakanda but moved to Oakland with his father. In both cases, the colour of their skin is viewed as the primary defining characteristic of their identity and leads to discrimination based on race.

\section{Preconceptions Outlined in T'Challa and Killmonger}

T'Challa, the protagonist, falls short at first but through struggle and by confronting his darkest fears saves not only himself but the world. This story follows a classical narrative, the typical myth of the hero. It is a universal storyline, but it is also predominantly Western (Slaats, 2018), and like the main characters, who are put against each other, present us with very simplified choices, and do not represent the nuanced intricacies of black lives in the US or Africa.

For starters, Killmonger's character reinforces a not-so-flattering stereotype of African American men, dangerous and obsessed with violence. Considering that this is a superhero film, heteropatriarchal violence is given. But the problem starts when the movie does not say that violence is not an acceptable form of black liberation, in fact, this is how Wakanda is liberated. (Serwer, 2020) The difference between instances of violence in the movie is that Killmonger is willing to kill his people in order to reach his goal, and that is where T'Challa draws the line, but he as well fights physically to protect what is important to him. Do we accept the use of violence as long as it is for our people's (in this case Black people's) sake? Does not that reinforce the differences between races all over again? This problem resurfaces throughout many aspects of the movie. For instance, when Shuri, T'Challa's sister and a brilliant inventor, seeing the CIA agent she is asked to heal, utters: "Oh great, another broken white boy for me to fix"; the message becomes clear that the West and white people are to be repaired. (Knowles, 2018) The moviemakers want to fight racism, I have no doubts about that, but what they do with emphasizing racial differences is no use to anyone, given the bitter undertone of such comments as Shuri makes.

A binary opposition is portrayed in the pitting of T'Challa against the African American Erik Killmonger as narrative stand-ins for Black people more broadly. Killmonger advocates a global revolutionary politics of overthrowing the oppressor, a position repudiated by his characterization as a haphazardly violent Black man whose willingness to kill his lover renders him decidedly immoral in comparison to the unwaveringly ethical T'Challa. Indicative of its limitations, Black Panther cannot portray Killmonger as a "Good" subject because ultimately the Good Black Man must be "grateful, compliant, silent, etc.". (Griffin, 2018: 364) Jenna N. Hachey compares the two heroes from a moral point of view and says that T'Challa represents the "Good Black Man" and Killmonger the "Bad Black Man". T'Challa is the saviour who helps the African diaspora and Killmonger stands as the violent angry protagonist, influenced by his upbringing as a poor orphan. By this logic, the movie connects morality with development, economic security and technological advance- 


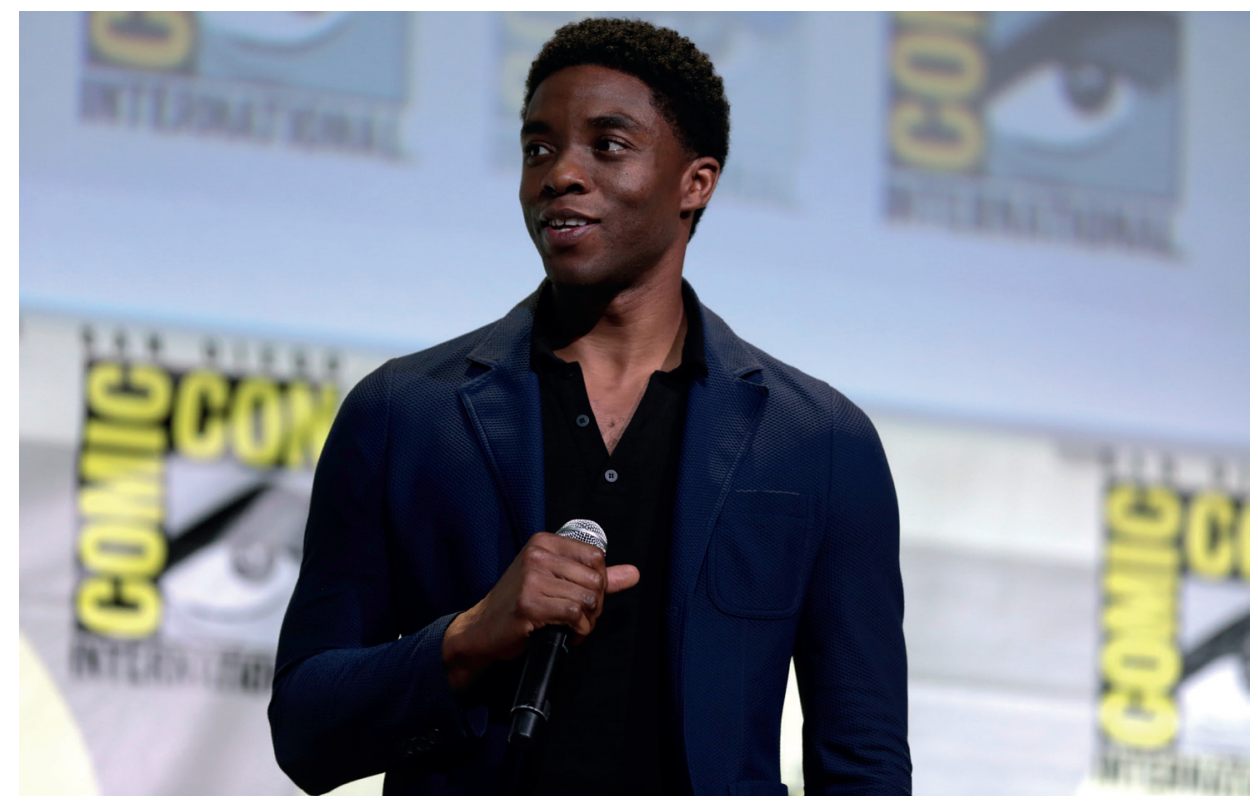

Chadwick Boseman speaking at the 2016 San Diego Comic Con International, for "Black Panther", at the San Diego Convention Center in San Diego, California. Source: Gage Skidmore, wikimedia.

ment; and poverty with immoral behaviour. (Hanchey, 2020) Hanchey shines a light on this fact and contends that it again strengthens stereotypical thinking.

In addition, T'Challa is willing to put his principles aside when Agent Ross needs medical help, filling the role of the aid-giver once again. It can be viewed as a representation of a coalition between the US and Africa, enhancing the neoliberal respectability of T'Challa, but carries a contradiction, since the CIA's history with Africa includes the suppression of democratic movements. It seems that what matters for T'Challa is to be respected by these institutions, seen as an equal, rather than challenge them and their imperialistic ways. (Asante-Pind, 2020: 225) The ending of the film reflects this very well, when King T'Challa addresses the United Nations. He proclaims that the time has come for Wakanda to share its technology and be a part of the "white" world, not change it. Politics is replaced by mere recognition of racialized difference as an inclusion. (Asante-Pind, 2020: 225)

Killmonger's character is depicted as the result of the American military-industrial complex, in the movie Agent Everett even says "he is one of us". His methods are aligned with that, since he is following the US imperialist patterns of expansion to bring "democracy" to his people. It shows the contradictory logic of the US' attempt to "save" underdeveloped countries but undermine their economic independence at the same time. White says that giving credit to Killmonger is to accept that he understands persecution. (White, 2018: 426) He does to a certain degree, but only from a diasporic point of view, unlike T'Challa who grew up in Wakanda, in Africa. 
But he also sees one side of the coin, his royal upbringing kept him sheltered from the realities of how systemic racism has touched every black life across the globe. (Smith, n.d.) The movie brings the difference of Black-consciousness forward, and tries to show how it is anchored differently in specific places.

\section{Conclusion: Inspiring Futures}

Let me steer towards the conclusion with an anecdote that Ytasha Womack tells in a conference in Amsterdam about her visit to a primary school in Chicago. She was presenting about Afrofuturism and what it means, starting with some questions about how pupils would imagine the future would be like. The kids gave surprising answers, considering they were 10-year-olds. All of them, in different ways, said that they would like a future without violence, a future without guns. Womack was shocked that the kids' imagination could not break the boundaries of their surroundings, social situation and the picture the media painted of them. However, by the end of the discussion the students realized with the use of their imagination they can create a world they would want to live in and like that, influence reality. They gained a sense of agency within their lives through this exercise. (Womack, 2017) "When we talk about the world of the imagination and speculative fiction, basically the realms of creative arts, it's not just a form of expression, it does ultimately create levels of agency. People will have a feeling that they can shape the world around them." (Womack, 2017) Black Panther is the first movie in a long time, in which black people have a lot of agency. Jamie Broadnax, the founder of Black Girl Nerds, states that these characters "are rulers of a kingdom, inventors and creators of advanced technology. We're not dealing with black pain, and black suffering, and black poverty" - the usual themes of acclaimed films about the black experience. (Wallace, 2018)

For me one of the greatest contributions of the "post" era is the notion that identities are created, they are a form of social construct. Indicative of that, they can be changed through discussion. "Africa and African identities both as states of being and becoming. They are dynamic historical processes, messy spatio-temporal configurations of agency, structure and contextuality that are subject to change [...]" (Zeleza, 2006: 19) Afrofuturism is one potentially useful tool for change. It is self-healing for people of African descent, helping to transcend circumstances and disrupting people's usual way of looking at reality. They will start to think about: What are my default assumptions about the world? What ideas are acceptable and which are not? Visualizing other kinds of worlds pushes us beyond our conventions and helps shape a better future. Most of the time activists are working on an issue and it takes decades to bring about change, but writing a story or making a movie can be an instant inspiration and a therapy as well.

Can Black Panther help to reshape the future? Despite all of its shortcomings my answer is still yes. The film achieved the single most important thing to make a difference: it starts conversations. It raises awareness and puts Blackness and its hardships into public consciousness, while inspiring Black people to create a world of their ow 


\section{Bibliography}

- Asante, G. A. \& Pind G. N. (2020). (Re)imagining African futures: Wakanda and the politics of transnational Blackness, Review of Communication, 20:3, 220-228. [online]. Available at: https://www.tandfonline.com/doi/full/10.1080/15358593.2020.1778072 [01.11.2020.]

- Cole, T. (2012). The White-Savior Industrial Complex, The Atlantic, 21 March [online]. Available at: https://www.theatlantic.com/international/archive/2012/03/the-white-saviorindustrial-complex/254843/ [08.11.2020.]

- Dean, T. \& Andrews, D. P. (2016). Introduction: Afrofuturism in Black Theology - Race, Gender, Sexuality, and the State of Black Religion in the Black Metropolis, Black Theology, 14:1, 2-5. [online]. Available at: https://www.tandfonline.com/doi/full/10.1080/14769948.2015.1 131499 [01.11.2020.]

- Eshun, K. (2003). "Further Considerations of Afrofuturism", CR: The New Centennial Review 3, no. 2: 287-302. [online ].Available at: http://www.essayfilmfestival.com/wp-content/ uploads/2015/03/3.2eshun.pdf [06.11.2020.]

- Gathara, P. (2018). "Black Panther" offers a regressive, neocolonial vision of Africa, Washington Post, 16 February [online]. Available at: https:/www.washingtonpost.com/news/ global-opinions/wp/2018/02/26/black-panther-offers-a-regressive-neocolonial-vision-of-africa/ [20.01.2021.]

- Griffin, R. A. \& Rossing, J. P. (2020). "Black Panther in widescreen: cross-disciplinary perspectives on a pioneering, paradoxical film," Review of Communication, 20:3, 203-219. [online]. Available at: https://www.tandfonline.com/doi/full/10.1080/15358593.2020.1780467? $\mathrm{src}=$ recsys [02.11.2020.]

- Griffin, R. A. (2018). The Spectacularization and Serialization of Whiteness: Theorizing 50+ Years of O. J. Simpson's Contentious Notoriety, Communication, Culture \& Critique 11., no. 3

- Griffin, R.A. (2015). "Problematic Representations of Strategic Whiteness and 'Post-racial' Pedagogy: A Critical Intercultural Reading of The Help," Journal of International and Intercultural Communication 8, no. 2: 147-66.

- Griffin, R. A. (2012). "I AM an Angry Black Woman: Black Feminist Autoethnography, Voice, and Resistance," Women's Studies in Communication 35, no. 2: 148.

- Hanchey, J. N. (2020). Decolonizing aid in Black Panther, Review of Communication, 20:3, 260-268. [online]. Available at: https://www.tandfonline.com/doi/full/10.1080/15358593.2020 .1778070 [03.11.2020.]

- Harris, F. L. (2020) "Tell me the story of home": Afrofuturism, Eric Killmonger, and Black American malaise, Review of Communication, 20:3, 278-285.

- Hudson, M.(2018). Why was the Black Panther film so popular?, Britannica [online]. Available at: https://www.britannica.com/story/why-was-the-black-panther-film-so-popular [20.01.2021.]

- Khan, T.R., (2019). "Viewing Black Panther through a Postcolonial Feminist Lens," Women and Language 42, no. 1: 97-104.

- Knowles, M. (2018). REVIEW: 'Black Panther' is terrible, but it gets one thing right, Daily Wire, 19 February [online]. Available at: https:/www.dailywire.com/news/review-black-panther-terrible-it-gets-one-thing-michael-j-knowles?utm_source $=$ adwords\&utm_term $=\& u$ tm campaign $=$ Dynamic + Search +-+ Debate + Series $+($ Readers + Pass $) \& u t m \_$medium $=$ppc\&hsa $\mathrm{kw}=\& \mathrm{hsa}$ ad $=439463588562 \& \mathrm{hsa} \quad \mathrm{src}=\mathrm{g} \& \mathrm{hsa}$ ver $=3 \& \mathrm{hsa}$ grp $=99318280782 \& \mathrm{hsa}$ cam $=10215749899 \& \mathrm{hsa}$ tgt $=\mathrm{dsa}-915453078617 \& \mathrm{hsa}$ acc $=6411461344 \& \mathrm{hsa}$ mt $=$ b\&hsa_net $=$ adwords\&gclid $=$ Cj0KCQiAjKqABhDLARIsABbJrGn6c5fEAiivwx0C $\bar{C}$ VbI_ixz8vxpMaSrS_OB-O557SsW_0z_OJ1zYd_YaAp2zEALw_wcB [20.01.2021.]

- Lebron, C. (2018). 'Black Panther' Is Not the Movie We Deserve," Boston Review: A Political and Literary Forum, February 17 [online]. Available at: http://bostonreview.net/race/christopher-lebron-black-panther [01.11.2020.]

- Lowe, C. (1997). “Talking about 'Tribe': Moving from Stereotypes to Analysis,” pamphlet, Africa Policy Information Center, Washington, DC. [online]. Available at: http://kora.matrix. msu.edu/files/50/304/32-130-153D-84-Background_Paper_010_opt.pdf. [03.11.2020.] 
- Mbembe, A. (2001). On the Postcolony, University of California Press, Berkeley.

- Moyo, D. (2009). Dead Aid: Why Aid Is Not Working and How There Is a Better Way for Africa, Farrar, Straus, and Giroux, New York.

- Mtshali, K. K: (2018). "Black Panther Is Great. But Let's Not Treat It as an Act of Resistance," Guardian, 15 February [online]. Available at: https://www.theguardian.com/commentisfree/2018/feb/15/black-panther-resistance. [03.11.2020.]

- Nelson, A. (2002). "Introduction: Future Texts," Social Text 20, no. 2: 1-20. [online]. Available at: https://read.dukeupress.edu/social-text/article/20/2\%20(71)/1/32617/IntroductionFUTURE-TEXTS [02.01.2021.]

- Rathod, A. (2019) How Technology has Provided an Edge to the Filmmaking Industry, 9 August [online]. Available at: https://www.raindance.org/how-technology-has-provided-anedge-to-the-filmmaking-industry/ [06.11.2020.]

- Samatar, S. (2018). "Toward a Planetary History of Afrofuturism," Research in African Literatures 48, no. 4: 175-91

- Schmitt, C., Semu, L. L. \& Witte, M. D. (2017). Racism and transnationality, Transnational Social Review, 7:3, 239-243 [online]. Available at: https://www.tandfonline.com/doi/ full/10.1080/21931674.2017.1359959 [05.11.2020.]

- Serwer, A. (2018). "The Tragedy of Erik Killmonger," The Atlantic, 21 February [online]. Available at: https://www.theatlantic.com/entertainment/archive/2018/02/black-panther-erikkillmonger/553805/ [05.11.2020.]

- Seymour, M. (2018). Making Thanos Face The Avengers, Fxguide, 7 May [online]. Available at: https://www.fxguide.com/fxfeatured/making-thanos-face-the-avengers/ [06.11.2020.]

- Slaats, J. (2018). 15 reasons why Black Panther is a nationalist, xenophobic, colonial and racist movie, KIFKIF, 23 May [online]. Available at: https://kifkif.be/cnt/artikel/15-reasons-whyblack-panther-nationalist-xenophobic-colonial-and-racist-movie-6036 [21.01.2021.]

- Smith, J. (n.d.) The Revolutionary Power of Black Panther: Marvel's New Movie Marks a Major Milestone, Time [online]. Available at: https://time.com/black-panther/ [08.11.2020.]

- Wallace, C. (2018). Why 'Black Panther' Is a Defining Moment for Black America, The New York Times Magazine, 12 February [online]. Available at: https://www.nytimes. com/2018/02/12/magazine/why-black-panther-is-a-defining-moment-for-black-america.html [02.11.2020.]

- White, R. T. (2018) “I Dream a World: Black Panther and the Re-Making of Blackness," New Political Science 40, no. 2

- Womack, Y. L. (2017). Afrofuturism: Imagination and Humanity, SONIC ACTS FESTIVAL - THE NOISE OF BEING, 26 February - De Brakke Grond, Amsterdam, The Netherlands [online]. Available at: https://www.youtube.com/watch?v=xlF9:0sXVfKk\&feature=share [10.01.2021.]

- Womack, Y. L. (2013). Afrofuturism: The World of Black Sci-Fi and Fantasy Culture, Lawrence Hill, Chicago.

- Wynter, S. (2003). "Unsettling the Coloniality of Being/Power/Truth/Freedom: Towards the Human, After Man, Its Overrepresentation-An Argument," CR: The New Centennial Review 3, no. 3: 257-337.

- Zeleza, P. T. (2018) "Black Panther and the Persistence of the Colonial Gaze," Medium, 3 April [online]. Available at: https://medium.com/@USIUAfrica/black-panther-and-the-persistenceof-the-colonial-gaze-6c093fa4156d

- Zeleza, P. T. (2006). The Inventions of African Identities and Languages: The Discursive and Developmental Implications. In Selected Proceedings of the 36th Annual Conference on African Linguistics, ed. Olaoba F. Arasanyin and Michael A. Pemberton, 14-26. Cascadilla Proceedings Project, Somerville, MA. [online]. Available at: http://www.lingref.com/cpp/ acal/36/paper1402.pdf [22.20.2021.] 